
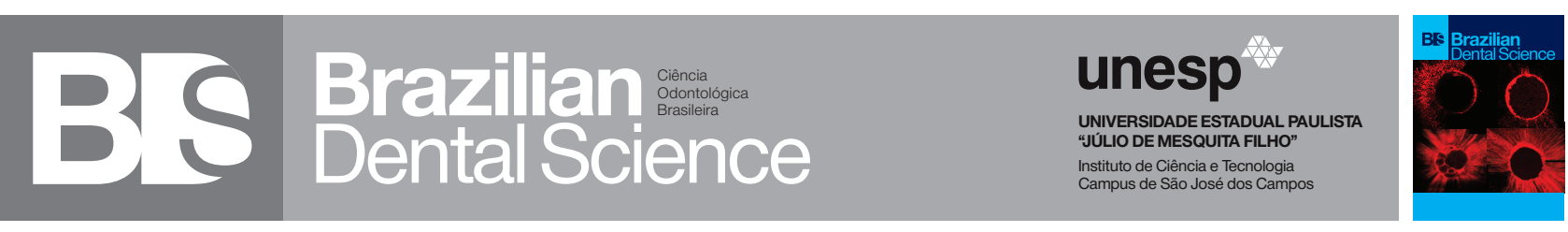

\title{
Assessment of remineralization potential of Theobromine and Sodium Fluoride gels on Artificial Caries like lesions
}

\author{
Avaliação do potencial de remineralização de géis de teobromina e fluoreto de sódio em lesões de cárie artificial \\ Mohamed Saber ELSHERBINI ${ }^{1,2}$ \\ 1 - Orthodontics \& Pediatric Dentistry Department - College of Dentistry - Qassim University. Qassim, KSA. \\ 2 - Pediatric Dentistry and dental public health Department, Faculty of Oral and Dental Medicine, Assiut University. Assiut, Egypt.
}

\section{ABSTRACT}

Objective: To compare the remineralization potential of theobromine and sodium fluoride gels on artificial caries like lesion. Materials and Methods: Forty longitudinal halves of human mandibular premolars were equally divided into 4 groups of 10 samples each: control group (C), samples were stored in distilled water during the experiment period. The remaining 30 specimens were subjected to demineralization protocol to create caries like lesions. samples were immersed for three days in a demineralization solution (pH 5.0) containing 0.2\% carbopol and 0.1\% lactic acid saturated with calcium phosphate tribasic. The samples were subdivided into 3 equal groups according to the treatment applied during the $\mathrm{pH}$ cycle. Demineralization group "D": no treatment applied. Group "F" treated with $2000 \mathrm{mg} /$ liter sodium fluoride gel. Group "T" treated with $200 \mathrm{mg} /$ liter theobromine gel. The specimens of the two studies groups were subjected to Demineralization- Remineralization $\mathrm{PH}$ Cycle Protocol for 5 days (Alternating four steps: 1: Treatment material, fluoride or theobromine $\cong 3$ minutes. 2: Demineralizing solution 3 hours. 3 : treatment material $\cong 3$ minutes. 4: Remineralizing solution till the next cycle). The samples were investigated by scanning electron microscope (SEM) and energy dispersive $\mathrm{x}$-ray analysis (EDXA). Results: The enamel of the demineralization group was porous with artificial caries like changes exposing the subsurface enamel rods with severe rod core defects. Theobromine gel and fluoride

\section{RESUMO}

Objetivo: Comparar o potencial de remineralização dos géis de teobromina e fluoreto de sódioem lesões de cáries artificiais. Materiais e Métodos: Quarenta metades longitudinais de pré-molares inferiores humanos foram igualmente divididas em 4 grupos de 10 amostras cada: grupo controle (C), as amostras foram armazenadas em água destilada durante o período doexperimento. As 30 amostras restantes foram submetidas ao protocolo de desmineralização paracriar lesões artificiais de cárie. As amostras foram imersas por três dias em uma solução dedesmineralização (pH 5,0 ) contendo $0,2 \%$ de carbopol e $0,1 \%$ de ácido lático saturado comfosfato de cálcio tribásico. As amostras foram subdivididas em 3 grupos iguais, de acordo com otratamento aplicado durante o ciclo do $\mathrm{pH}$. Grupo de desmineralização " $D$ ": nenhum tratamentoaplicado. Grupo " $\mathrm{F}$ " tratado com $2000 \mathrm{mg} /$ litro de fluoreto de sódio em gel. Grupo \& quot;T \&q uot; tratadocom $200 \mathrm{mg} /$ litro de gel de teobromina. As amostras dos dois grupos de estudo foramsubmetidas ao protocolo de ciclo de desmineralização - remineralização por 5 dias (quatroetapas alternativas: 1: material de tratamento, flúor ou teobromina $\cong 3$ minutos. 2: soluçãodesmineralizante 3 horas. 3 : material de tratamento $\cong 3$ minutos 4 : Solução de remineralizaçãoaté o próximo ciclo). As amostras foram investigadas por microscopia eletrônica de varredura(MEV) e análise de raios- $\mathrm{X}$ dispersivos de energia (EDXA). Resultados: O esmalte do grupo dedesmineralização era poroso, com cáries artificiais, como alterações que expunham as 
gel groups showed marked improvement in the surface characteristics in the enamel in both groups. Theobromine gel group showed more observable enamel surface improvement than the fluoride gel group. EDXA revealed that the calcium-phosphorus ratio displayed a descending order: $(\mathrm{C}>\mathrm{T}>\mathrm{F}>\mathrm{D})$. The differences between the two tested groups were not statistically significant. Conclusion: Theobromine gel had more effective remineralizing potential than fluoride gel as a result of its effect in improving the enamel surface characteristics of human teeth.

\section{KEYWORDS}

Dental caries; Dental enamel, Ultrastructure; Hardness; Microscopy; Electron; Scanning; Sodium Fluoride, Therapeutic use; Theobromine/therapeutic use.

\section{INTRODUCTION}

$\mathrm{D}$ ental caries forms through localized destruction of dental hard tissues by a complex interaction over time between acid-producing bacteria and fermentable carbohydrates and have many host factors including teeth and saliva [1]. Furthermore, the process of enamel de- and remineralization is governed by the degree of saturation of oral fluids (saliva and plaque) concerning apatite minerals [1].

Any interruption in the balance between demineralization and remineralization leads to caries $[2,3]$. However, dental caries in its early stages of formation can be remineralized [4].

Prevention of enamel demineralization would certainly be a better choice than treatment of the lesion. Numerous preventive measures have been employed in the past. hastes deesmalte do subsolo com graves defeitos no núcleo da haste. Os grupos gel de teobromina e flúorapresentaram melhora acentuada nas características da superfície do esmalte nos dois grupos. Ogrupo gel de teobromina mostrou uma melhoria na superfície do esmalte mais observável doque o grupo gel de fluoreto. A EDXA revelou que a razão cálcio-fósforo exibia uma ordemdecrescente: (C\&gt; T\&gt; F\&gt; D). As diferenças entre os dois grupos testados não foramestatisticamente significantes. Conclusão: O gel de teobromina teve um potencialremineralizante mais eficaz que o gel de flúor como resultado de seu efeito na melhoria dascaracterísticas da superfície do esmalte dos dentes humanos.

\section{PALAVRAS-CHAVE}

Cárie Dentária; Esmalte Dentário, ultraestrutura; Dureza; Microscopia,Elétron; Digitalização; Fluoreto de sódio, uso terapêutico; Teobromina, uso terapêutico.
These include oral hygiene instructions, diet modification, fluoride-releasing orthodontic products, fluoride varnishes, filled resin sealants5, and chlorhexidine varnishes [5-14].

Fluoride therapy is one of the most essential and effective modalities of caries prevention either in systemic mode (tablets, salt, milk, or water) [15] or topical fluoride application [16,17].

The cariostatic effects of fluoride can be attributed to several mechanisms of action with the predominant mechanism being its impact on the remineralization of demineralized enamel [18].

Calcium fluoride, calcium hydroxide, and fluorapatite are produced after fluoridation. These fluoride compounds protect the enamel surface and act as fluoride reservoirs $[19,20]$.

However, the effectiveness of fluoride to promote remineralization is limited by the 
availability of calcium and phosphate in saliva [21]. Therefore, further preventive measures are required besides fluoride therapy to control the caries process in high caries-risk individuals [22].

Various adjunctive products were presented in the last decades including casein phosphopeptide with amorphous calcium phosphate [23], Tri-Calcium Phosphate added to fluoride [24], glass Ionomer cement [25] and iron [26].

While studying the effect of caffeine on mineralization of teeth of rats, it was serendipitously discovered that theobromine (dimethyl xanthine) which is the same xanthine family as caffeine and is a white crystal powder, enhance crystallinity with less net dissolution of the various minerals from the enamel surface exposed to theobromine compared to non-theobromine group $[27,28]$.

The enamel surface microhardness was improved after theobromine application which could be an indication for the protective effects of theobromine on enamel [29,30]. Diverse studies were conducted comparing theobromine and fluoride but, their results were relatively inconsistent [31,32]. In a study done by Amaechi et al., 2013, it has been reported that theobromine may be a possible alternative to fluoride additives in dentifrices. Since theobromine, at a molar level 71 times less than that of fluoride showed remineralization ability on enamel lesions comparable to that of fluoride [31]. However Mahardhika et al., 2017, reported that theobromine and fluoride have similar effects on enamel surface and remineralization ability. Theobromine was more favorable as it is safer because of its low toxicity when compared to fluoride [32].

This study was designed to compare the efficacy of theobromine and fluoride gels in remineralization of artificial carious enamel in humans' teeth.

\section{MATERIAL AND METHODS}

\section{Sample selection and preparation}

Twenty sound human premolars recently extracted for orthodontic reasons from patients of age group (16-23) years were used in the present study. The teeth were obtained from the Oral and Maxillofacial Department, Faculty of Dentistry, Qassim University. A patient's signed consent was obtained upon extraction according to the Committee of Ethics, Faculty of Dentistry, Qassim University. An ethical approval was issued with a registration number of proposal: \# ST /62/ 2019.

They were selected according to the criteria presented by Zero,1995 [33]: good general health and no systemic disease; no use of drugs that modify salivary flow 60 days before the study; not having undergone radio/chemotherapy, absence of severe tooth wear, caries activity, inadequate restorations, gingival recession or braces; and no smoking habit nor bruxism.

The teeth were cleaned of debris/stains, and examined with transilluminator. Teeth without caries or enamel malformations were selected and cleaned with fluoride-free pumice to remove the remnants of pellicle from the buccal surface. After that, the teeth were disinfected and stored in fresh, renewed deionized water at $4{ }^{\circ} \mathrm{C}$ [34] till the beginning of the experimental procedures, not more than one month.

Each tooth was sectioned longitudinally in a buccolingual direction into two halves by a diamond disk with copious water coolant to avoid heat generation. Then by plain back diamond lapping film $(1 \mu \mathrm{m})$ in a MultiPrep TM Precision Polishing machine (Allied High Tech, USA), the enamel surface of each 
block was polished to achieve a flat surface. Following this, all surfaces of each block were painted with two coats of acid-resistant nail varnish except the buccal surface.

\section{Lesion Formation}

Forty halves of the sectioned teeth were divided into 4 equal groups (10 samples each):

- Control group "C"; 10 samples were stored in distilled water during the experiment period.

- The remaining 30 specimens were subjected to demineralization protocol to create caries like lesions guided by previous studies with minor modification [35,36]; samples were immersed for three days in a demineralization solution ( $\mathrm{pH}$ 5.0) containing $0.2 \%$ carbopol (BF Goodrich, Cleveland, $\mathrm{OH}$, USA) and $0.1 \%$ lactic acid (Sigma-Aldrich Chemical, St. Louis, MO, USA) saturated with calcium phosphate tribasic.

\section{Grouping}

- After the formation of caries like lesions, the specimens were subjected to Demineralization- Remineralization $\mathrm{pH}$ cycle for 5 days and subdivided into 3 equal groups according to the treatment applied during the $\mathrm{pH}$ cycle. Demineralization group "D": no treatment applied.

Group "F" treated with $2000 \mathrm{mg} /$ liter sodium fluoride gel (A, Germiphene, Brantford, Canada).

Groups "T" treated with $200 \mathrm{mg} /$ liter theobromine gel.

\section{Gel Formation}

The theobromine
(3,7-Dimethylxanthine) was supplied in
powder form. The solution of the material
was prepared by dissolution of the specified
concentration in deionized water. Then the gel

was obtained by the addition of hydroxyethyl cellulose powder to the solution (60 gm/liter).

\section{Demineralization- Remineralization PH Cycle Protocol [37]}

1 - Application of the treatment material (fluoride or theobromine) for a period $\cong \approx 3$ minutes;

2 - Immersion in the demineralizing solution for 3 hours (Same solution used in the demineralization step);

3 - Application of the treatment material (fluoride or theobromine) $\cong \approx 3$ minutes;

4 - Immersion in the remineralizing solution until the beginning of the next cycle.

Remineralizing solution is composed of (contained $1.5 \mathrm{mM}$ calcium chloride, $0.9 \mathrm{mM}$ sodium phosphate) with $\mathrm{PH}$ adjusted to 7 by addition of potassium hydroxide.

\section{SEM examination and Energy Dispersive X-ray Analysis (EDXA):}

The three-thirds of the buccal surface enamel (occlusal, middle and cervical third) of each sample was examined under the magnification of (500, 1000 and 2000) to evaluate the surface characteristics of enamel. The mineral content of enamel surface was quantitatively analyzed by using (EDXA) to chemically analyze and measure calcium (Ca) and phosphorus (P) atomic \% of each enamel sample under magnification (200x) to cover wide fixed area.

Each enamel sample was placed under a vacuum and excited to a higher energy state with an electron beam. As the electrons of each element fall back down to its original energy state, it emits x-ray energy at a different specified wavelength. 
The percentages of calcium (Ca) and phosphorus $(\mathrm{P})$ in all samples were calculated and the $\mathrm{Ca} / \mathrm{P}$ ratios were calculated as an indication of changes in mineral content during demineralization and remineralization. The mean values of the $\mathrm{Ca} / \mathrm{P}$ ratio were calculated for all groups. Results were tabulated and statistically analyzed using a one-way ANOVA test to compare between all groups. Finally, the Bonferroni post hoc test was done for pairwise comparison to compare between every 2 groups at significance level $\mathrm{p}<0.05$.

\section{Scanning Electron Microscopic results}

Assessment of the enamel covering the buccal surfaces of all the included groups showed different and varied appearance in each group.

In the control group, the enamel surface revealed even smooth enamel surface with absence of any gross porosity. Assessment of the cervical third revealed regular relatively smooth enamel surface with evident pericymata. The middle third didn't show evidence of the characteristic rod cross section, indicating that this flat surface is the intact outer rod less layer with, minute few depressions. The occlusal third did not showed any defects except in higher magnifications where shallow pits were occasionally seen (figure 1).

The teeth which were acid treated (demineralization group) demonstrated signs of deficiency in enamel: in the cervical third, the enamel surface was rough with numerous pits occupying apparent surface area. Higher magnification of the cervical region revealed that the pits are of variable depth and width, few of them are wide and others are deep. Regarding the middle third, wide overview displayed scattered electron-lucent defective changes. The occlusal third showed apparent defects which were detected in the interface between the highly affected and the moderately affected enamel surface (Figure 2).

The enamel surfaces treated with theobromine gel displayed enhanced surface characteristics. Cervical third showed relatively smooth enamel with occasional depressions. Middle third presented almost similar features of the cervical third. While the occlusal third showed more frequent defects in comparison to the cervical and middle thirds. Higher magnification of the occlusal third demonstrated noticeable circular shallow depressions with variable size and minute oval or irregular defects (Figure 3 ).

The fluoride gel group of teeth revealed sorts of improvement of the enamel status showed intact enamel surface with no observable defects in many areas. Middle third revealed less regular surface than that of the cervical third with areas of nonpitted defective changes. Examination of the occlusal third displayed almost similar surface characteristics of the middle third where the defective areas were observed. Shallow pits on enamel surface were occasionally seen with high magnifications (Figure 4). 


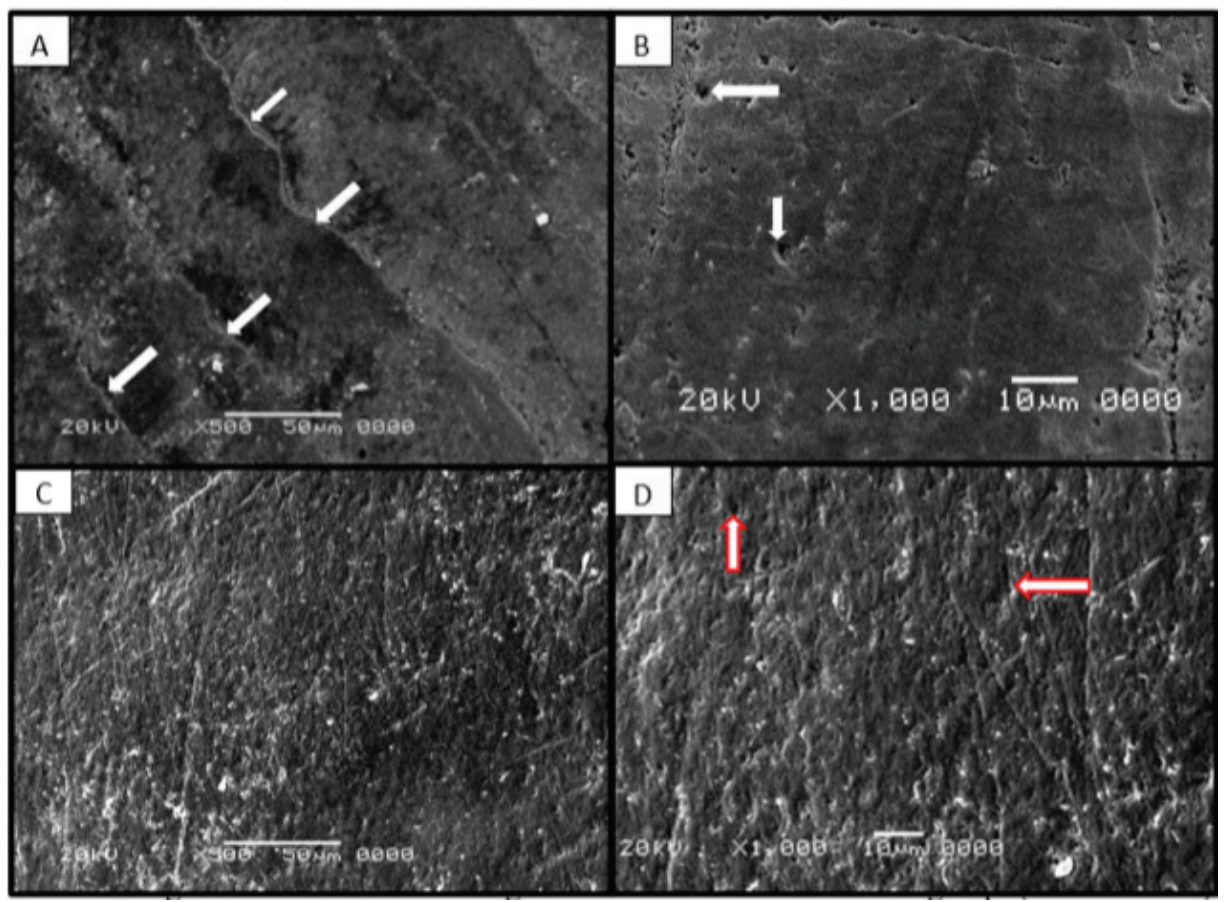

Figure 1 - Scanning electron micrographs of control group. (A): Cervical third showing intact enamel surface with observable perikymata (arrows). (B): Middle third displaying minute few depressions (arrows). (C): Occlusal third with no defects except in higher magnification (D): where shallow pits are occasionally seen (arrows) [Original magnification: A: 500, B: 1000, C: 500, D: 1000].

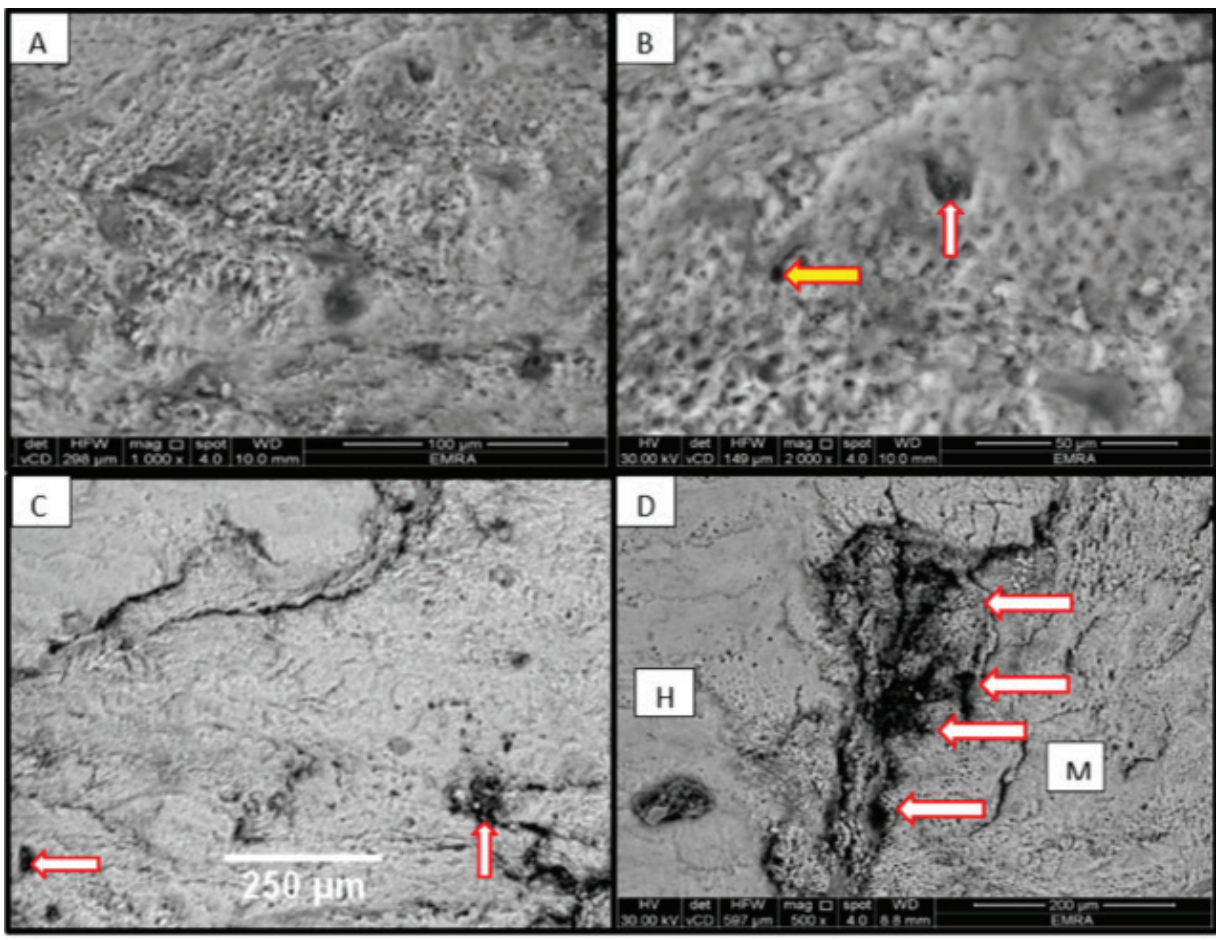

Figure 2 - Scanning electron micrographs of demineralization group. (A): Cervical third showing rough enamel surface with numerous pits occupying apparent surface area. (B): Higher magnification of the cervical region reveals that the pits are of variable depth and width, few of them are wide (white arrow) and others are deep (yellow arrow). (C): Middle third with wide overview displaying scattered electron-lucent defective changes (arrows). (D): Occlusal third showing apparent defects in the interface between the highly affected $(\mathrm{H})$ and the moderately affected $(\mathrm{M})$ enamel surface [Original magnification: A: 1000, B: 2000, C: 100, D: 500]. 


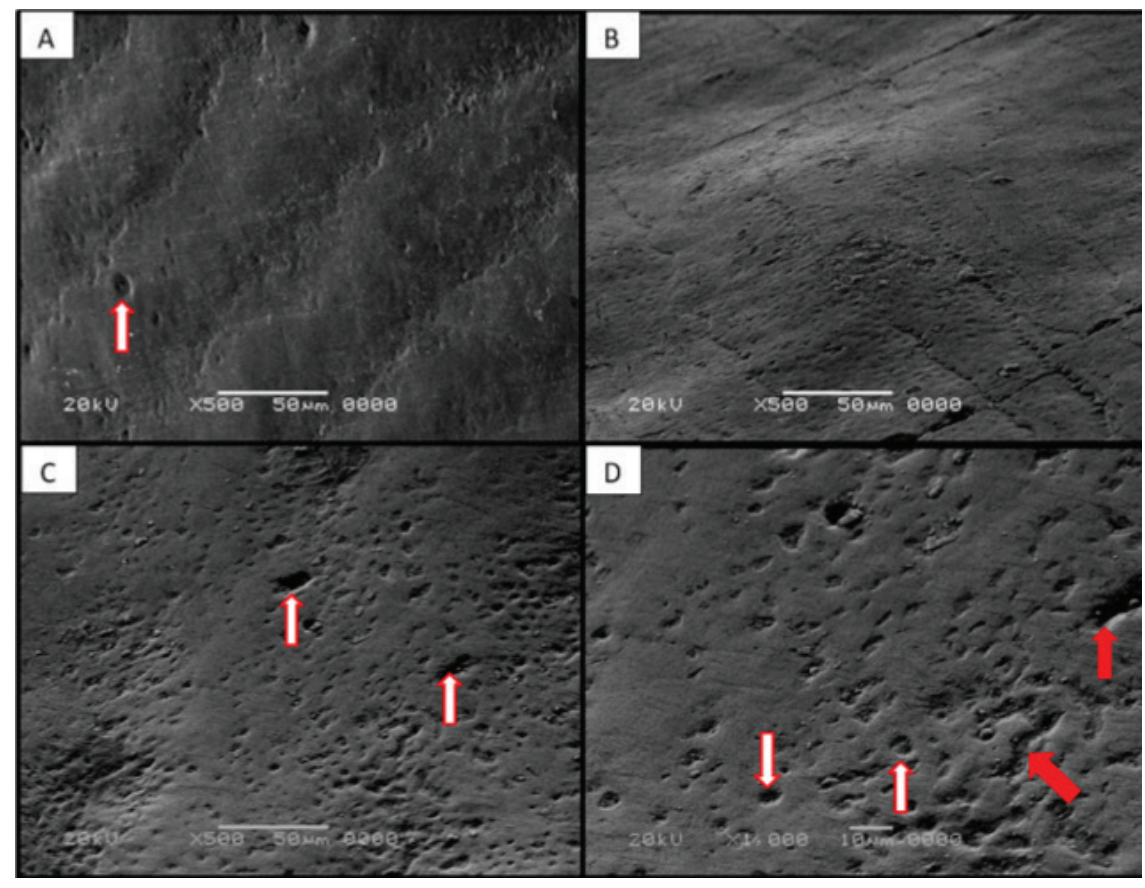

Figure 3 - Scanning electron micrographs of theobromine gel group. (A): Cervical third with relatively smooth enamel with occasional depressions (arrows) (B): Middle third presented almost similar features of the cervical third (C): Occlusal third showed more frequent defects in comparison to the cervical and middle thirds (arrows) (D): Higher magnification of the occlusal third demonstrated noticeable circular shallow depressions with variable size (white arrows) and minute oval or irregular defects (red arrows) [Original magnification: A: 500, B: 500, C: 500, D: 1000].

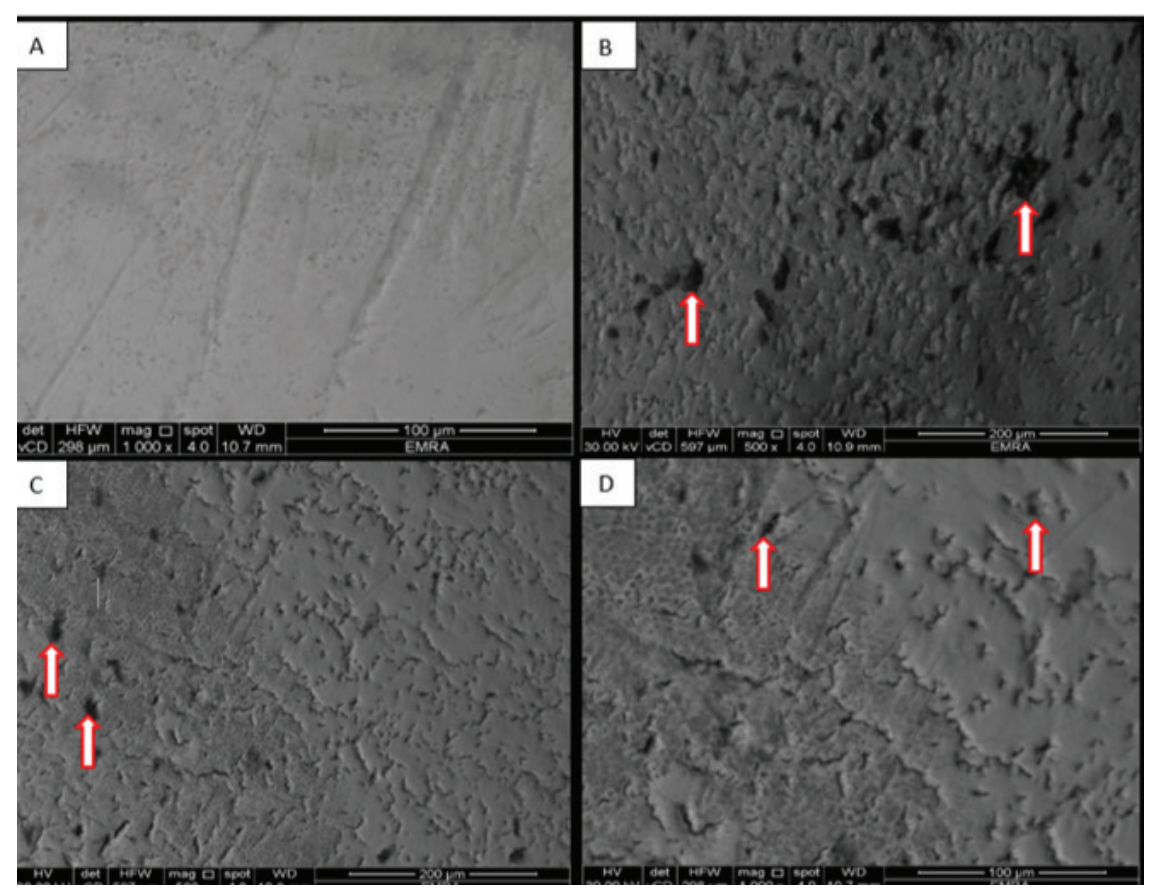

Figure 4 - Scanning electron micrographs of sodium fluoride gel group. (A): Cervical third showing intact enamel surface with no observable defects. (B): Middle third revealed less regular surface than that of the cervical third with areas of non-pitted defective change (arrows). (C): Occlusal third displayed almost similar surface characteristics of the middle third where the enamel defects areas are observed (arrows). (D): Shallow pits were occasionally seen with high magnifications (arrows) [Original magnification: A: 1000, B: 500, C: 500, D: 100 


\section{Energy Dispersive X-ray Analysis (EDXA) Results:}

The control group gave a high $\mathrm{Ca} / \mathrm{P}$ ratio with significance difference between the demineralization group and the two treatment groups ( $\mathrm{T} \& \mathrm{~F}$ groups). The highest $\mathrm{Ca} / \mathrm{P}$ ratio was in the theobromine gel followed by fluoride gel which showed no statistical difference between the two treatment groups. On the other hand, the demineralization group had the lowest $\mathrm{Ca} / \mathrm{P}$ ratio with statistical significance difference with all other groups.

There was a statistically significant difference between the demineralization group and the fluoride gel group and between the demineralization group and the theobromine gel group ( $\mathrm{P}$ value $<0.05$ ) while the other comparisons between the control group, the fluoride gel and theobromine gel groups were statistically non-significant (Table I).

Table I - Showing Comparison of Ca/P ratio for the four study groups.

\begin{tabular}{|c|c|c|c|c|c|}
\hline & \multirow{2}{*}{ Mean } & \multirow{2}{*}{ SD } & \multicolumn{2}{|c|}{$\begin{array}{l}\text { 95\% Confidence } \\
\text { Interval for Mean }\end{array}$} & \multirow{2}{*}{$F(p)$} \\
\hline & & & $\begin{array}{l}\text { Lower } \\
\text { Bound }\end{array}$ & $\begin{array}{l}\text { Upper } \\
\text { Bound }\end{array}$ & \\
\hline Control & 2.088765 & 0.1485034 & 1.982532 & 2.194998 & \multirow{4}{*}{$\begin{array}{c}32.426 \\
(p<0.001)^{\star}\end{array}$} \\
\hline Demineralization & 1.502053 & 0.1560586 & 1.390415 & 1.613690 & \\
\hline Fluoride & 1.725331 & 0.1345128 & 1.629107 & 1.821556 & \\
\hline Theobromine & 1.886980 & 0.1081249 & 1.809633 & 1.964328 & \\
\hline
\end{tabular}

\section{Benferroni Post-Hoc test for pairs comparisons}

\begin{tabular}{|c|c|c|c|c|}
\hline & Control & $\begin{array}{l}\text { Demineral- } \\
\text { ization }\end{array}$ & Fluoride & Theobromine \\
\hline \multicolumn{5}{|l|}{ Control } \\
\hline Demineralization & $P<0.001^{\star}$ & & & \\
\hline Fluoride & $p<0.001^{\star}$ & $0.005^{\star}$ & & \\
\hline Theobromine & $0.014^{\star}$ & $p<0.001^{*}$ & 0.077 & \\
\hline
\end{tabular}

*: significant at $p<0.05$

\section{DISCUSSION}

Caries prevention and early interception are major objectives in the applied dental science. The present work focused on the remineralization as a minimally invasive tool for reversing incipient caries. Although the enamel remineralization potential and its role in caries arresting are widely discussed in the literature [38]. There is an argument about the categorization of the remineralizing materials as well as the methods for the application of these materials.

This experiment sought to determine the capacity of Theobromine gel to promote the remineralization of artificially damaged human enamel. To strengthen our conclusions, the performance of theobromine was compared with that of a material that has long been its substitute in the market: sodium fluoride gel. The use of theobromine as a remineralization agent was based on research by Nakamoto that showed theobromine and fluoride to be two substances that can elevate apatite crystal size [39], which is related to enamel surface hardness. Nakamoto further stated that theobromine is safer because of its low toxicity level when compared to fluoride [39].

The theobromine gel concentration of $200 \mathrm{mg} / \mathrm{L}$ was selected based on research by Kargul and Nakamoto on the effectiveness of theobromine at different concentrations, 100 $\mathrm{mg} / \mathrm{L}$ and $200 \mathrm{mg} / \mathrm{L}$ ([29]. Their research demonstrated $200 \mathrm{mg} / \mathrm{L}$ theobromine to be more effective at increasing enamel surface hardness [29].

In the current study, enamel caries like lesions has been created by a chemical in vitro models due to their simplicity, low cost, and experimental stability [40]. The demineralizing solution used in the present work was mainly of acetic acid as it could cause detectable lesion formation, even at $\mathrm{pH} 5.0$ or higher [41]. The PH cycling models have been used in the current work to mimic the in vivo periodic alternation of $\mathrm{PH}$ and could exemplify the oral environment more closely than in traditional experimental designs [35]. 
Porous and defective areas in the enamel surface had been observed in the samples after exposure to the demineralizing solution. The application of demineralizing solution dissolves calcium and phosphate ions leading to the creation of gaps among crystals which, consequently, create surface porosity. Similar results were reported in the previous study done by Karlinsey et al. 2012 [42].

The buccal enamel surface has been examined by the electron microscope under the magnification of (500, 1000 and 2000) for the assessment of the enamel surface characteristics. Most of the previous studies were assessing only one-third of the enamel surface $[43,44]$, while in the current study, the three-thirds have been examined. The results revealed numerous defects areas and porosities in the occlusal thirds more than the other two thirds in the four groups. These might be attributed to the mastication forces loaded on the occlusal third, variations in diet intake and/or parafunctional habits which cause more enamel attrition $[45,46]$.

In the present work, SEM demonstrated an improvement in the enamel surface characteristics in the treated two groups with different degrees. Regarding the porosity, theobromine gel group showed generally more satisfactory results than that of the fluoride gel group. This might be attributed to the improvement of remineralization by adsorption to the surface of the demineralized crystals and attraction of calcium ions [30]. The current study showed remarkable consistent results with Sadeghpour et al. 2007 who stated that theobromine causes calcium and phosphate to merge into a crystal unit that is four times bigger than hydroxylapatite [47].

In the present study, EDXA revealed more improved $\mathrm{Ca} / \mathrm{P}$ ratio in the theobromine gel group than in the fluoride groups, but these results were statistically non-significant. On the contrary, Kargul et al. 2012 [29] reported a superior effect of fluoride in increasing the surface microhardness of the demineralized enamel more than all theobromine. The controversy might be due to the difference in the fluoride form as the authors used acidulated phosphate fluoride while in our work, we used sodium fluoride.

The improvement in the chemical composition of enamel surface with the theobromine gel group agreed with Nakamoto et al. who concluded that theobromine caused the formation of larger HAP crystallites in vitro [39]. Furthermore, the study results of Sadeghpour et al. 2007 revealed that theobromine makes calcium and phosphate to merge into a crystal unit that is a fourfold bigger than hydroxyapatite [47]. Our results stated that although theobromine gel caused an increase in the $\mathrm{Ca} / \mathrm{P}$ ratio but didn't reach the level of the control group. This coincides with Herisa et al. 2017 [48] who showed that theobromine enhanced the hardness of enamel surface after demineralization but did not restore it to its initial hardness.

\section{CONCLUSIONS}

Within the revealed results, the present study concluded that there were remineralizing potentials from the two tested materials with more potent effect in the theobromine gel with no statistically significant difference. More in vivo studies are necessary to confirm this hypothesis.

\section{Acknowledgments}

The author is indebted to Khaled El-Sayed El-Haddad, Assistant Professor, Department Of Oral Biology, Faculty Of Oral And Dental Medicine, Ain Shams University. And Dr. Ramy Elmoazen, Lecturer of Community Dentistry, Qassim University, KSA for their excellent monitoring of the laboratory work.

\section{REFERENCES}

1. Margolis HC, Moreno EC. Kinetics of hydroxyapatite dissolution in acetic, lactic, and phosphoric acid solutions. Calcif Tissue Int. 1992;50(2):137-43. doi:10.1007/bf00298791.

2. O'Mullane DM. Introduction and rationale for the use of fluoride for caries prevention. Int Dent J. 1994;44(3 Suppl 1):257-61. 
3. Zero DT. Dental caries process. Dent Clin North Am. 1999;43(4):635-64.

4. Espelid I. Caries preventive effect of fluoride in milk, salt and tablets: a literature review. Eur Arch Paediatr Dent. 2009;10(3):149-56. doi:10:1007/ bf03262676.

5. Sudjalim TR, Woods MG, Manton DJ. Prevention of white spot lesions in orthodontic practice: a contemporary review. Aust Dent J. 2006;51(4):284-347. doi:10.1111/j.1834-7819.2006.tb00445.x.

6. Chadwick BL, Roy J, Knox J, Treasure ET. The effect of topical fluorides on decalcification in patients with fixed orthodontic appliances: a systematic review. Am J Orthod Dentofacial Orthop. 2005;128(5):601-70. doi:10.1016/j. ajodo.2004.07.049.

7. Benson PE, Shah AA, Millett DT, Dyer F, Parkin N, Vine RS. Fluorides, orthodontics and demineralization: a systematic review. J Orthod. 2005;32(2):102-14. doi:10.1179/146531205225021033.

8. Derks A, Katsaros C, Frencken JE, van't Hof MA, Kuijpers-Jagtman AM. Caries-inhibiting effect of preventive measures during orthodontic treatment with fixed appliances. A systematic review. Caries Res. 2004;38(5):413-20. doi:10.1159/000079621.

9. Benson PE, Parkin N, Millett DT, Dyer FE, Vine S, Shah A. Fluorides for the prevention of white spots on teeth during fixed brace treatment. Cochrane Database Syst Rev. 2004;(3):CD003809. doi:10.1002/14651858.CD003809. pub2.

10. Mandall NA, Millett DT, Mattick CR, Hickman J, Worthington HV, Macfarlane TV. Orthodontic adhesives: a systematic review. J Orthod. 2002;29(3):205195. doi:10.1093/ortho/29.3.205.

11. Rinchuse DJ, Brady TA, Sahlaney JJ. Fluoride usage in orthodontics: considerations and concerns. J Clin Orthod. 1997;31(4):227-30.

12. Chang HS, Walsh LJ, Freer TJ. Enamel demineralization during orthodontic treatment. Aetiology and prevention. Aust Dent J. 1997;42(5):322-7. doi:10.1111/j.1834-7819.1997.tb00138.x.

13. Erickson RL, Glasspoole EA. Model investigations of caries inhibition by fluoride-releasing dental materials. Adv Dent Res. 1995;9(3):315-31. doi:10. 1177/08959374950090031801.

14. Chadwick BL. Products for prevention during orthodontics. Br J Orthod 1994;21(4):395-8. doi:10.1179/bjo.21.4.395.

15. Featherstone JD. Dental caries: a dynamic disease process. Aust Dent J. 2008;53(3):286-91. doi:10.1111/j.1834-7819.2008.00064.x.

16. Thurnheer T, Belibasakis GN. Effect of sodium fluoride on oral biofilm microbiota and enamel demineralization. Arch Oral Biol. 2018;89:77-83. doi:10.1016/j.archoralbio.2018.02.010.

17. Hamdan WA, Badri S, El Sayed A. The effect of fluoride varnish in preventing enamel demineralization around and under orthodontic bracket. Int Orthod. 2018;16(1):1-11. doi:10.1016/j.ortho.2018.01.005.

18. McDonald RE, Avery DR, Stookey GK. Prevention of dental caries. In: McDonald RE, Avery DR, Dean JA, editors. Dentistry for child and adolscents. Saint Louis: Mosby; 2004.

19. Gerth HU, Dammaschke T, Schäfer E, Züchner H. A three layer structure model of fluoridated enamel containing $\mathrm{CaF} 2, \mathrm{Ca}(\mathrm{OH}) 2$ and FAp. Dent Mater. 2007;23(12):1521-8. doi:10.1016/j.dental.2006.12.007.

20. Campillo M, Lacharmoise PD, Reparaz JS, Goñi AR, Valiente M. On the assessment of hydroxyapatite fluoridation by means of Raman scattering. J Chem Phys. 2010;132(24):244501. doi:10.1063/1.3428556.

21. Mandel ID. Impact of saliva on dental caries. Compend Suppl. 1989;(13):S476-S81.
22. Featherstone JD, Doméjean $\mathrm{S}$. The role of remineralizing and anticaries agents in caries management. Adv Dent Res. 2012;24(2):28-31. doi:10.1177/0022034512452885.

23. Cross KJ, Huq NL, Reynolds EC. Casein phosphopeptides in oral health-chemistry and clinical applications. Curr Pharm Des. 2007;13(8):793-800. doi:10.2174/138161207780363086.

24. Karlinsey RL, Mackey AC, Walker ER, Frederick KE. Preparation, characterization and in vitro efficacy of an acid-modified beta-TCP material for dental hard-tissue remineralization. Acta Biomater. 2010:6(3):969-78. doi:10.1016/j.actbio.2009.08.034.

25. Shimazu K, Ogata K, Karibe H. Caries-preventive effect of fissure sealant containing surface reaction-type pre-reacted glass ionomer filler and bonded by self-etching primer. J Clin Pediatr Dent. 2012;36(4):343-7. doi:10.17796/jcpd.36.4.n444r730r773un53.

26. Alves KM, Franco KS, Sassaki KT, Buzalaf MA, Delbem AC. Effect of iron on enamel demineralization and remineralization in vitro. Arch Oral Biol. 2011;56(11):1192-8. doi:10.1016/j.archoralbio.2011.04.011.

27. Nakamoto T, Cheuk SL, Yoshino S, Falster AU, Simmons WB. Cariogenic effect of caffeine intake during lactation on first molars of newborn rats. Arch Oral Biol. 1993;38(10):919-22. doi:101016/0003-9969(93)90103-s.

28. Schneider PE, Alonzo G, Nakamoto T, Falster AU, Simmons WB. Effects of caffeine intake during gestation and lactation on the acid solubility of enamel in weanling rats. Caries Res. 1995;29(4):285-90. doi:10.1159/000262083.

29. Kargul B, Özcan M, Peker S, Nakamoto T, Simmons WB, Falster AU. Evaluation of human enamel surfaces treated with theobromine: a pilot study. Oral Health Prev Dent. 2012;10(3):275-82.

30. Syafira G, Permatasari R, Wardani N. Theobromine effects on ename surface microhardness: in vitro. J Dent Indonesia. 2012; 19(2):32-6. doi: 10.14693/jdi.v19i2.138.

31. Amaechi BT, Porteous N, Ramalingam K, Mensinkai PK, Ccahuana Vasquez $\mathrm{RA}$, et al. Remineralization of artificial enamel lesions by theobromine. Caries Res. 2013;47(5):399-405. doi:10.1159/000348589.

32. Mahardhika A, Noerdin A, Eriwati YK. The effects of brushing on human enamel surface roughness after $\mathrm{NaF}$ gel and theobromine gel exposure. J Phys Conf Ser. 2017; 884(1):012007· doi: 101088/1742-6596/884/1/012007.

33. Zero DT. In situ caries models. Adv Dent Res. 1995;9(3):214-34. doi:10.1177/ 08959374950090030501.

34. Kim Y, Son HH, Yi K, Kim HY, Ahn J, Chang J. The color change in artificial white spot lesions measured using a spectroradiometer. Clin Oral Investig. 2013;17(1):139-46. doi:10.1007/s00784-012-0680-x

35. Ten Cate JM, Duijsters PP. Alternating demineralization and remineralization of artificial enamel lesions. Caries Res. 1982;16(3):201-10. doi:10.1159/000260599.

36. Tschoppe P,Zandim DL, Martus P, Kielbassa AM. Enamel and dentine remineralization by nano-hydroxyapatite toothpastes. J Dent. 2011;39(6):430-7. doi:10.1016/j.jdent.2011.03.008.

37. Argenta RM, Tabchoury CP, Cury JA. A modified pH-cycling model to evaluate fluoride effect on enamel demineralization. Pesqui Odontol Bras. 2003;17(3):241-6. doi:10.1590/s1517-74912003000300008.

38. Abou Neel EA, Bozec L, Perez RA, Kim HW, Knowles JC. Nanotechnology in dentistry: prevention, diagnosis, and therapy. Int J Nanomedicine. 2015:10:6371-94. Published 2015 0ct 8. doi:10.2147/IJN.S86033. 
39. Nakamoto T, Falster AU, Simmons WB. Theobromine: a safe and effective alternative for fluoride in dentifrices. J Caffeine Res. 2016;6(1):1-9. doi: 10.1089/jcr.2015.0023.

40. Yu OY, Zhao IS, Mei ML, Lo EC, Chu CH. A Review of the Common Models Used in Mechanistic Studies on Demineralization-Remineralization for Cariology Research. Dent J (Basel). 2017;5(2):20. Published 2017 Jun 18. doi:10.3390/dj5020020.

41. Featherstone JD, Rodgers BE. Effect of acetic, lactic and other organic acids on the formation of artificial carious lesions. Caries Res. 1981;15(5):377-85. doi:10.1159/000260541.

42. Karlinsey RL, Mackey AC, Blanken DD, Schwandt CS. Remineralization of eroded enamel lesions by simulated saliva in vitro. Open Dent J. 2012;6:170-6. doi:10.2174/1874210601206010170.

43. Lanigan LT, Bartlett DW. Tooth wear with an erosive component in a Mediaeval Iceland population. Arch Oral Biol. 2013;58(10):1450-6. doi:10.1016/j.archoralbio.2013.06.019.

44. Kaidonis J, Richards L, Townsend G. Non-carious changes to tooth crowns. Graham JM, Hume WR. (eds). Preservation and restoration of tooth structure. Queensland: Knowledge Books and Software; 2005. p.47-60.
45. Jansson C, Wallander MA, Johansson S, Johnsen R, Hveem K. Stressful psychosocial factors and symptoms of gastroesophageal reflux disease: a population-based study in Norway. Scand J Gastroenterol. 2010;45(1):21-9. doi:10.3109/00365520903401967.

46. Bader G, Lavigne G. Sleep bruxism; an overview of an oromandibular sleep movement disorder. Review article. Sleep Med Rev. 2000;4(1):27-43. doi:10.1053/smrv.1999.0070.

47. Sadeghpour A. A neural network analysis of theobromine vs. fluoride on the enamel surface of human teeth. An experimental case study with strong implications for the production of a new line of revolutionary and natural non-fluoride based dentifrices. Diss Abstr Int. 2007;68(7) suppl.B:150.

48. Herisa HM, Noerdin A, Eriwati YK. The effect of theobromine $200 \mathrm{mg} / \mathrm{l}$ topical gel exposure duration against surface enamel hardness resistance from 1\% citric acid. JPhys Conf Ser. 2017, 884: 012009. doi: 10.1088/17426596/884/1/012009.

\section{Mohamed Saber Elsherbini}

\section{(Corresponding address)}

College of Dentistry,

Qassim University, Qassim, KSA.

Date submitted: 2019 Dec 11

E-mail: dr_saber1@hotmail.com 